\title{
Erasmus+ programs- the need to create a competitive space of the Romanian education system
}

\author{
Luminița-Claudia CORBU \\ Stefan cel Mare University of Suceava, Suceava, Romania \\ luminitaclaudia@yahoo.com
}

\begin{abstract}
The need to create a competitive framework of the Romanian education system and the current needs of the labor market have aroused the interest of the human resource in the pre-university education, which manifests its interest towards the European funds that can be attracted in the field of education and which are necessary for the creation of a context that raises the education system to the standards of the European Union, a fact also demonstrated by the legislation in force. By the Government Decision no. 76 / 27.01.2005 and the Government Decision no. 67/2007 has been designated the National Agency for Community Programs in the Field of Education and Vocational Training ("Agency", AN), as an agency for implementing the community programs "Lifelong Learning" (LLP), "Youth in action" ( YiA) and Erasmus Mundus from 2007-2013. This document included the Europass National Center, the Eurydice National Unit and the Eurodesk National Office in the AN. In 2013, through the Government Memorandum no. 10988/ 09.12.2013, AN was designated as the Implementing Agency for the Erasmus + program, from 2014-2020, having as a mission the administration of the European Union program that supports the national project for the better change of communities, attitudes and mentalities of individuals. Erasmus $+i$ is the EU program in the fields of education, training, youth and sport for the period 2014-2020. Education, training, youth and sport make a significant contribution to combating socio-economic change, to Europe's greatest challenges by the end of the decade, and to the implementation of the European policies for growth, jobs, equity and social inclusion. Combating the rising unemployment rate - especially among young people, has become one of the most urgent tasks of European governments. Too many young people leave school prematurely, thus risking becoming unemployed and socially marginalized. The same risk threatens many low-skilled adults. The technologies change the way the company operates, so their full use is necessary. European companies need to become more competitive through talent and innovation. Europe needs more cohesive and inclusive societies that enable citizens to play an active role in democratic life. Education and youth activities are essential elements for preventing radicalization through violence and by promoting common European values, social inclusion, enhancing interculturality and a sense of belonging to a community. Erasmus + is an important tool for promoting the integration of people from disadvantaged backgrounds, of newly arrived migrants, responding to critical events affecting European countries. The Erasmus + program aims to help the countries participating in the program to effectively use Europe's talent and social capital, in a lifelong learning perspective, by linking the support provided to formal, non-formal and informal learning in the fields of education, training and youth.
\end{abstract}

Keywords: Erasmus+, education system, European Union.

\section{Introduction}

An educated workforce is essential for ensuring productivity growth and therefore for achieving economic growth. While this may be considered an impetus for the public subsidization of education, some political debates have advocated in this regard to increase private investments in education through the higher rates of return obtained at all levels of education ${ }^{1}$. This statement is also substantiated and argued by the fact that a higher degree of education of the workforce generates the increase of the production capacity in two ways: the education gives the workers the necessary skills, thus increasing their productivity, and the increase of the innovation capacity of the workers leads to the increase of their own productivity as well as of

\footnotetext{
${ }^{1}$ Arcalean, C., Schiopu, I. (2010). Public versus private investment and growth in a hierarchical education system.Journal of Economic Dynamics and Control, 34(4). 604-622.
} 
other workers ${ }^{2}$. Investments in education materialize throughout the life cycle in earnings for the sake of education, and their level and development are determined by several factors. The high level of unemployment is associated with the level of education. Heckman and Jacobs (2010) developed a model for the training, use and maintenance of skills, of partial equilibrium type throughout the life cycle of education, on-the-job training, job offers, saving and retirement. They pointed out that investing in human capital reveals dynamic complementarities throughout the life cycle, even after the initial education period, the gains on the initial education are higher if a person is more engaged in on-the-job training, and individuals with a high level of individual education invest more in training in the workplace ${ }^{3}$.

\section{Romanian Education system and Erasmus+programs}

Erasmus + is the EU program in the fields of education, training, youth and sport for the period 2014-2015. Education, training, youth and sport can make a major contribution to addressing socio-economic change, the main challenges Europe will face by the end of the decade, and to implementing the European policy agenda for growth, jobs, equity and social inclusion. Combating the level of rising unemployment - especially among young people - has become one of the most urgent tasks for European governments. Too many young people drop out of school prematurely, thus risking becoming unemployed and socially marginalized. The same risk threatens many low-skilled adults. The technologies change the functioning of the company, so it is necessary to use them to the maximum capacity. European businesses need to become more competitive through talent and innovation. Europe needs more cohesive and inclusive societies that enable citizens to play an active role in democratic life. Education and youth activities are essential elements for preventing violent radicalization and for promoting common European values, social integration, strengthening interculturalities and a sense of belonging to an Erasmus community + an important tool for promoting the inclusion of people from disadvantaged backgrounds, in particular of newly arrived migrants, in response to critical events affecting European countries. Another challenge concerns the development of social capital among young people, the emancipation of young people and their ability to actively participate in society, in accordance with the provisions of the Lisbon Treaty, in order to "encourage the participation of young people in the democratic life of Europe". This aspect can also be addressed through non-formal learning activities, which aim to improve the skills and competences of young people, as well as to promote active citizenship. Also, youth organizations and young workers need training and cooperation opportunities to develop the professionalism and European dimension of youth work. High-performance education and training systems and youth policies can contribute to addressing these challenges, providing citizens with the necessary skills in the labor market and in the economy, while allowing them to play an active role in society and to be realized on a personal level. Reforms in education, training and youth can strengthen the achievement of these objectives, based on a shared vision between policy makers and stakeholders, solid evidence and cooperation between different fields and levels. The Erasmus + program is designed to support the efforts of the countries participating in the program to effectively use Europe's talent and social capital, in a perspective of lifelong learning, by linking support for formal, non-formal and informal learning in the fields of education., training and youth. In line with one of the elements recently introduced in the Lisbon Treaty, Erasmus + also supports activities aimed at developing the European dimension in sport, by promoting cooperation between bodies responsible for sport. The program promotes the creation and development of European networks, providing opportunities for cooperation between stakeholders and for the exchange and transfer of knowledge and

\footnotetext{
2 The World Bank- MENA DEVELOPMENT REPORT, 2008, pag. 41.

${ }^{3}$ Hekman,J., \& Jacobs, B. (2010).POLICIES TO CREATE AND DESTROY HUMAN CAPITAL IN EUROPE, NATIONAL BUREAU OF ECONOMIC RESEARCH, 1050 Massachusetts Avenue Cambridge, MA 02138.
} 
know-how in different fields related to sport and physical activity. The enhanced cooperation will have positive effects, especially in developing the potential of Europe's human capital, contributing to reducing the social and economic costs of physical inactivity. In table no.1 the specific objectives of the Erasmus+program are presented.

Table no.1 Erasmus + program in the field of education and training - specific objectives SPECIFIC OBJECTIVES OF THE ERASMUS + PROGRAM IN THE FIELD OF EDUCATION AND TRAINING

\begin{tabular}{|c|c|}
\hline $\begin{array}{l}\text { - improving the level of competences and key skills, } \\
\text { especially regarding their relevance to the labor } \\
\text { market and to their contribution to strengthening social } \\
\text { cohesion; }\end{array}$ & $\begin{array}{l}\text { - increasing the mobility opportunities for educational } \\
\text { purposes and strengthening the cooperation between } \\
\text { the field of education and training and the field of } \\
\text { work; }\end{array}$ \\
\hline $\begin{array}{l}\text { - fostering quality improvement, excellence in } \\
\text { innovation and internationalization at the level of } \\
\text { education and training institutions; }\end{array}$ & $\begin{array}{l}\text { - promoting the emergence of a European lifelong } \\
\text { learning space and raising awareness about it; }\end{array}$ \\
\hline $\begin{array}{l}\text { - Improving the international dimension of vocational } \\
\text { education and training, in particular through } \\
\text { cooperation between institutions in the participating } \\
\text { countries and partners in the field of vocational } \\
\text { education and training. }\end{array}$ & $\begin{array}{l}\text { - improving the teaching and learning of foreign } \\
\text { languages and promoting the EU's wide linguistic } \\
\text { diversity, as well as raising awareness of its cultural } \\
\text { dimension. }\end{array}$ \\
\hline
\end{tabular}

Source: Own elaboration based on data collected from www.erasmusplus.ro.

\section{Quantitative research on the opinions of the students and teachers participating in the key action 2 (KA2) of the Erasmus + program from the perspective of the interconnection of the level of education with other European education systems in the context of economic growth}

In order to highlight the results obtained, by implementing the Erasmus Plus programs, and the objectives pursued by them, we focused on the key action 2- regarding the mobility of people (in our case, students and teachers), an action that is presented at European level through a significant number of projects implemented in this regard. This action involves an exchange of experience between different European education systems on different topics, for example: democracy, intercultural education, human rights, tolerance, etc.

The participants of this research were teachers and students from different European countries that took part in the project: Spain-Catalonia, Italy, Holland, Romania, Germany and even Turkey. We will call the group of participants in this research a "batch", because we do not have a sample that was made on the basis of sampling rigor and that was extracted from the population. Participants are selected based on availability and involvement in the funded project called The Voice of Young Europe. This project proposes to the students to discuss topics of their choice, for example: European citizenship important or not for today's youth?, human rights - their advantages, migration or emigration - advantages and disadvantages, teacherstudent relations, school and its role in student life; multiculturalism, free movement of people etc. During the entire mobility period, the Romanian students were able to discover their communication skills in a foreign language, to be part of the daily program of a foreign student, living with him and participating with him in all his activities. The strategic partnership took place over a period of 36 months, between 2014-2017, and the exchange of experience took place between the following countries: Spain, Italy, Holland, Germany and Romania. Turkey was withdrawn from the project, the reason being its geographical location, the Turkish school was on the border with Syria, and the political problems of this period generated uncertainty, the mobility of students in this area presenting a major risk. The Netherlands was the main coordinator of the project, and the other countries were partners. It should also be mentioned that the lot contains disproportionate data and there is no equal distribution of participants in each category represented by the research variables. Therefore, for the question about learning new structures or learning styles, we had 30 teacher participants and the same number of student 
participants. For items aimed at increasing the competence of using the computer, 28 teacher participants answered 25 before participating in the program and a batch of 35 student participants before participating in the project, and another batch of 25 students after participating in the project. 30 teachers and 30 students answered the question regarding communication and cooperation.Finally, to the question "Has your project determined you to become more inclined to practice as a team, in the near future?"30 teachers and 30 students answered.The questionnaire for students and the questionnaire for teachers were applied in 2016, both of which were edited in English.

Statistical analysis. To identify the effect of European projects on human resource development, we used The Voice of Young Europe project database, in which we analyzed the impact that this project has on both teachers and students. In the case of teachers, the language of the research was English, so the questionnaires are written in this language, and regarding the students, the questionnaires were written and applied either in the language of origin of each country participating in the project or in English.

\section{THE EFFECT OF EUROPEAN FUNDS ON THE DEVELOPMENT OF HUMAN RESOURCES IN PRE-UNIVERSITY EDUCATION}

The teachers were asked if they learned during the course of the project new methods or styles of teaching-learning-evaluation (Have you learned new debating structures or styles?), Being asked to respond dichotomically with "yes" or "no". The result indicates that a large proportion of respondents from different European countries, such as Spain-Catalonia, Italy, Holland, Romania, Scotland and Turkey (about 3 times more respondents) reported that the European project had a positive result ( $73 \%$ ) and only $27 \%$ answered negative.

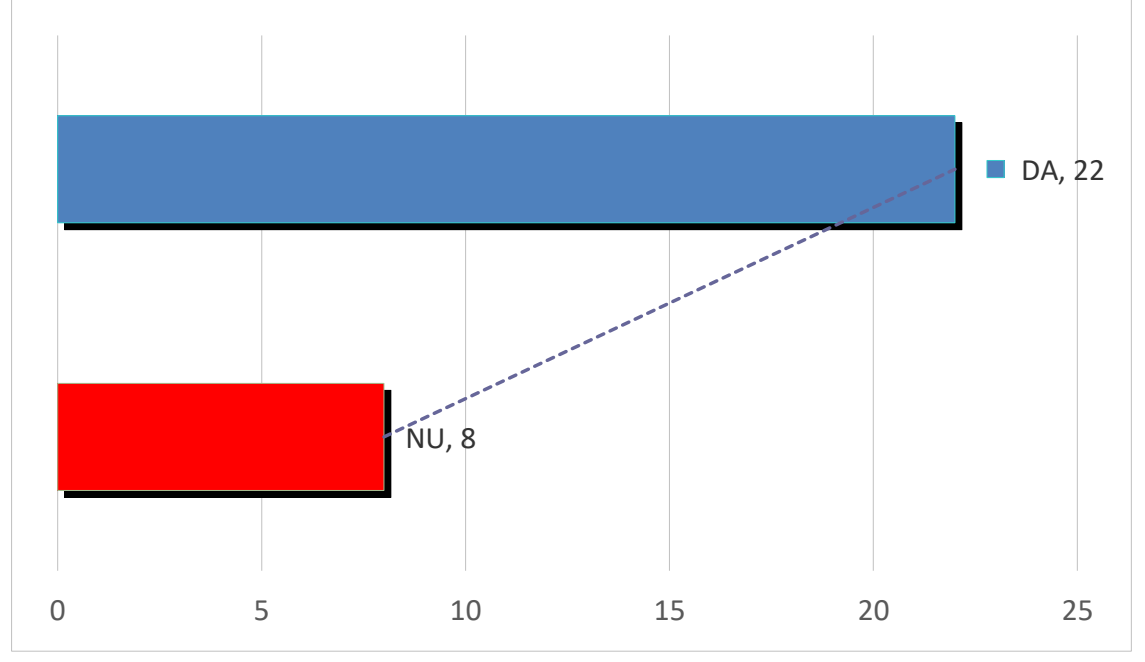

Figure no. 1 Teacher response on learning debate structures or styles

Source: Own elaboration based on the analysis in SPSS 22.

Another measurement concerned the skills of using the computer.Teachers were asked to self-report the extent to which they possessed computer operating knowledge and skills prior to the project and after participating in the project. The tool contained six items related to personal purchases before and after project participation that related to using Office Word, Film editing, Power Point, Skype, Hangout, or Google Drive software. To perform the statistical analysis we used the $t$ test for paired samples which is a test of significance and that tests the differences between two environments. The results are presented in Table no.2, Table no.3 and Table no.4. 
Table no.2 Statistical results of the group involved in the Erasmus + program

\begin{tabular}{|l|c|c|c|c|c|}
\hline & Moment_evaluation & $\mathrm{N}$ & Mean & Std. Deviation & Std. Error Mean \\
\hline \multirow{2}{*}{ Level_knowledge_use } & Before & 28 & 17.3571 & 4.18298 & .79051 \\
\cline { 2 - 6 } & After & 25 & 19.8800 & 4.50296 & .90059 \\
& \multicolumn{7}{|c|}{ Source: Own elaboration based on the analysis in SPSS 22.} \\
\hline
\end{tabular}

The arithmetic mean of the level of knowledge before participating in the European program is $\mathrm{M}$ after $=17,3571$, and the average after participation is $\mathrm{M}$ befor $=19.8800$. From a media point of view, there is a difference, but we do not know if it is significant or not.For this we check the results of the $t$ test. The result indicates that there is a strong correlation between the two variables: $r=.949$, and $p=.000$.

Tableno.3 The stages of correlating the samples analyzed in the project

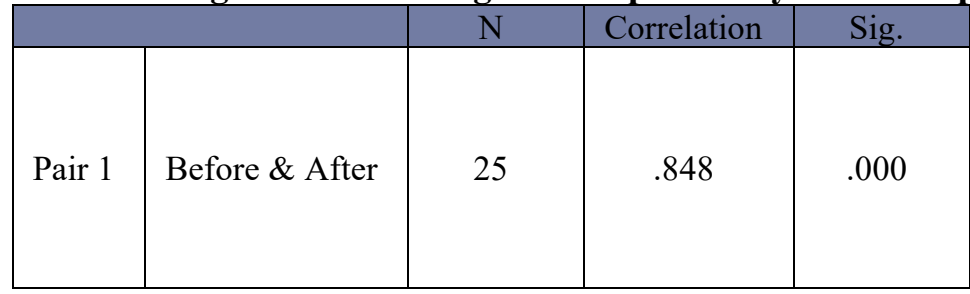

Source: Own elaboration based on the analysis in SPSS 22.

The statistical results in the SPSS indicate that there is a significant difference between the average of the knowledge of the use of the computerized means before participating in the project, compared to the time of the project completion:

$\mathrm{t}(24)=-4,410, \mathrm{sig}=0.000$

Table no.4 The stages of correlating the samples analyzed before and after participating in the project

\begin{tabular}{|c|c|c|c|c|c|c|c|c|}
\hline & \multicolumn{5}{|c|}{ Paired Differences } & \multirow{3}{*}{$\mathrm{t}$} & \multirow{3}{*}{ df } & \multirow{3}{*}{$\begin{array}{l}\text { Sig. (2- } \\
\text { tailed) }\end{array}$} \\
\hline & \multirow[t]{2}{*}{ Mean } & \multirow[t]{2}{*}{$\begin{array}{c}\text { Std. } \\
\text { Deviation }\end{array}$} & \multirow[t]{2}{*}{$\begin{array}{l}\text { Std. Error } \\
\text { Mean }\end{array}$} & \multicolumn{2}{|c|}{$\begin{array}{l}95 \% \text { Confidence } \\
\text { Interval of the } \\
\text { Difference }\end{array}$} & & & \\
\hline & & & & Lower & Upper & & & \\
\hline \begin{tabular}{|l|l} 
Pair 1 $1 \begin{array}{l}\text { Before } \\
\text { After }\end{array}$ \\
\end{tabular} & -2.12000 & 2.40347 & .48069 & -3.11210 & -1.12790 & -4.410 & 24 & .000 \\
\hline
\end{tabular}

Source: Own elaboration based on the analysis in SPSS 22.

As the result of the $t$ test is less than 0.05 , we will consider that there is a significant difference between the two averages. In other words, the average of the knowledge of operating the computer means, after participating in the project is significantly higher than before participating in the same project. This means that there is a significant effect of the variable "participation in the training offered by the project" on "the development of the human resource" 


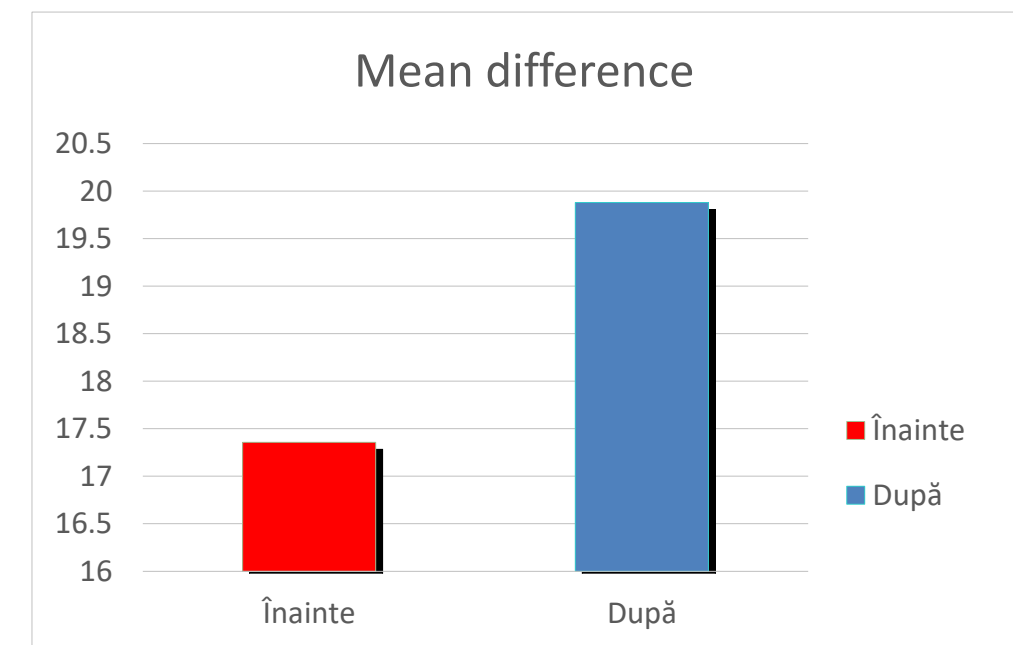

PICBE | 1076

Figure no.2 The difference of environments regarding the knowledge of computer use before and after participating in the program

Source: Own elaboration based on the analysis in SPSS 22.

Another question to which the respondents provided answers was to what extent the teacher-student communication and cooperation improved following participation in the project.The self-reported responses, according to the perception of the participants, were overwhelmingly positive: $93.3 \%$ of the participants answered positive and only $6.7 \%$ answered negative.

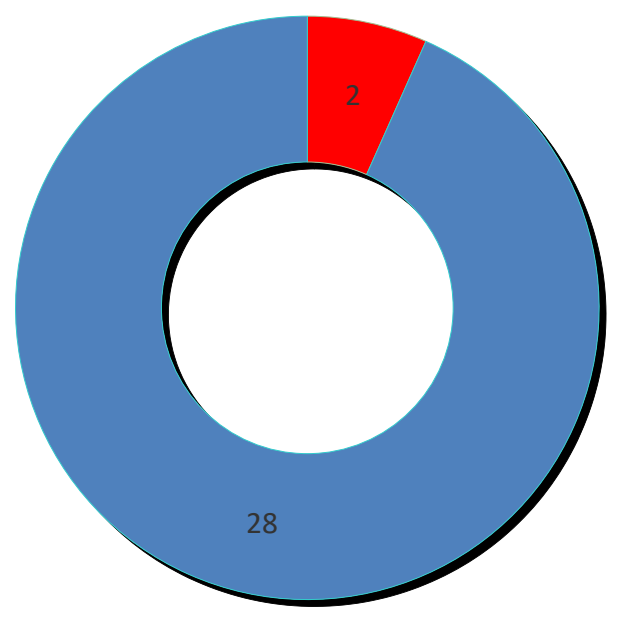

Figure no.3 Frequency of participants' responses regarding improving communication and cooperation between teachers and students Source: own elaboration based on the analysis in SPSS 22.

Also, when asked, "Has your project determined you to become more inclined to practice teamwork in the future?", The respondents unanimously affirmed: 


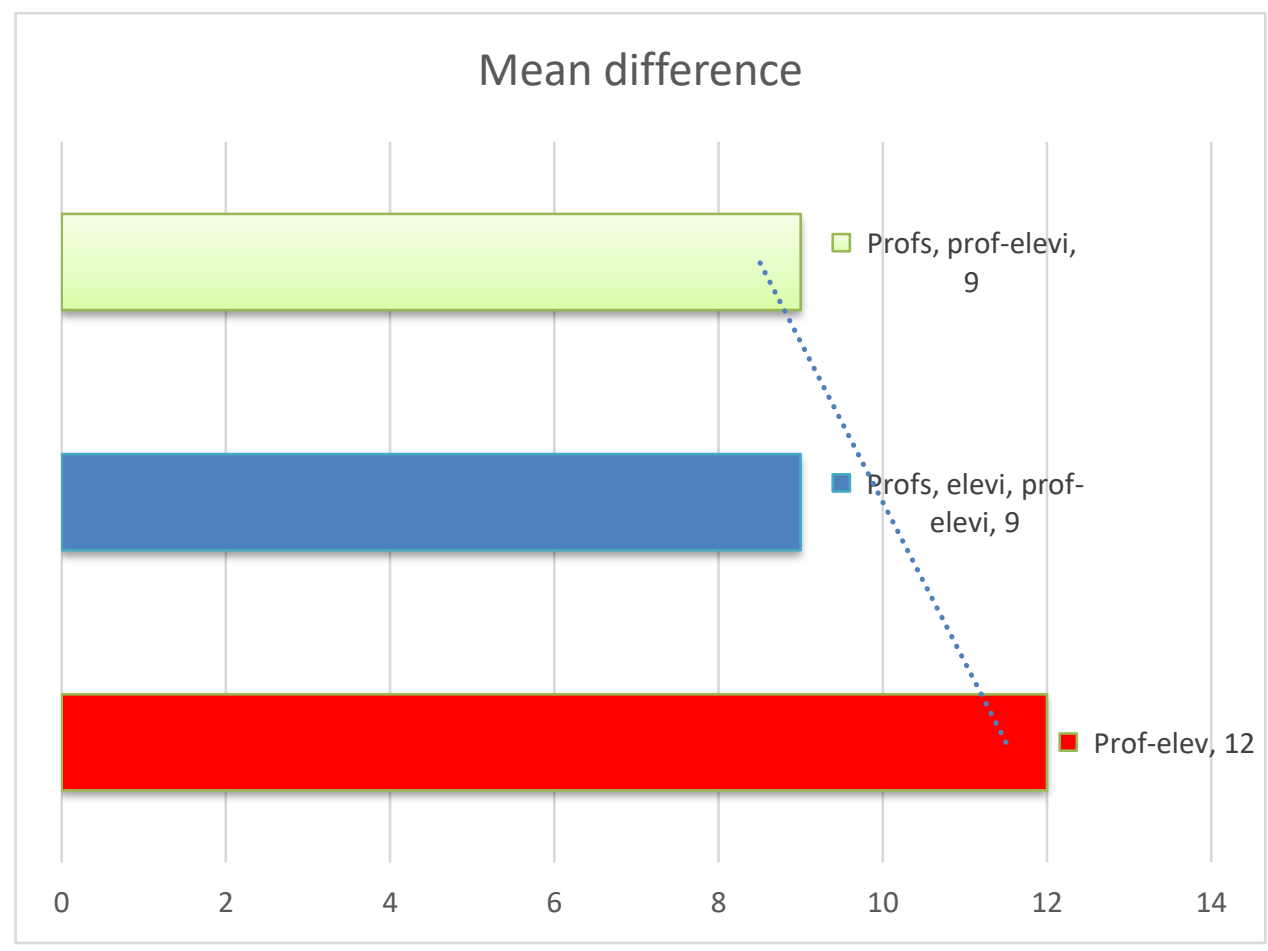

Figure no.4 Participants' answers regarding teamwork

Source: own elaboration based on the analysis in SPSS 22.

Of the research respondents, $40 \%$ indicated that the project helped them to become more predisposed to teamwork in the teacher-student relationship and 30\% stated that the project contributed to improving teamwork skills in the teacher relationship and in the teacher relationship. and students. At the same time, $30 \%$ of the participants reported that, as a result of the program, the efficiency of teamwork in the mentioned relationships increased: teacherteacher,teacher-student.

\section{THE EFFECT OF EUROPEAN FUNDS ON THE DEVELOPMENT OF HUMAN RESOURCE FOR THE STUDENTS}

The students were asked if they had learned during the project development new methods or styles (Have you learned new debating structures or styles?) By being asked to respond dichotomically with "yes" or "no". The result indicates that a large proportion of respondents from different European countries, such as Spain-Catalonia, Italy, the Netherlands, Romania, Scotland and Turkey, reported that the European project had a positive result $(54.90 \%, \mathrm{~N}=60)$ and only $45.10 \%$ negative answered. 


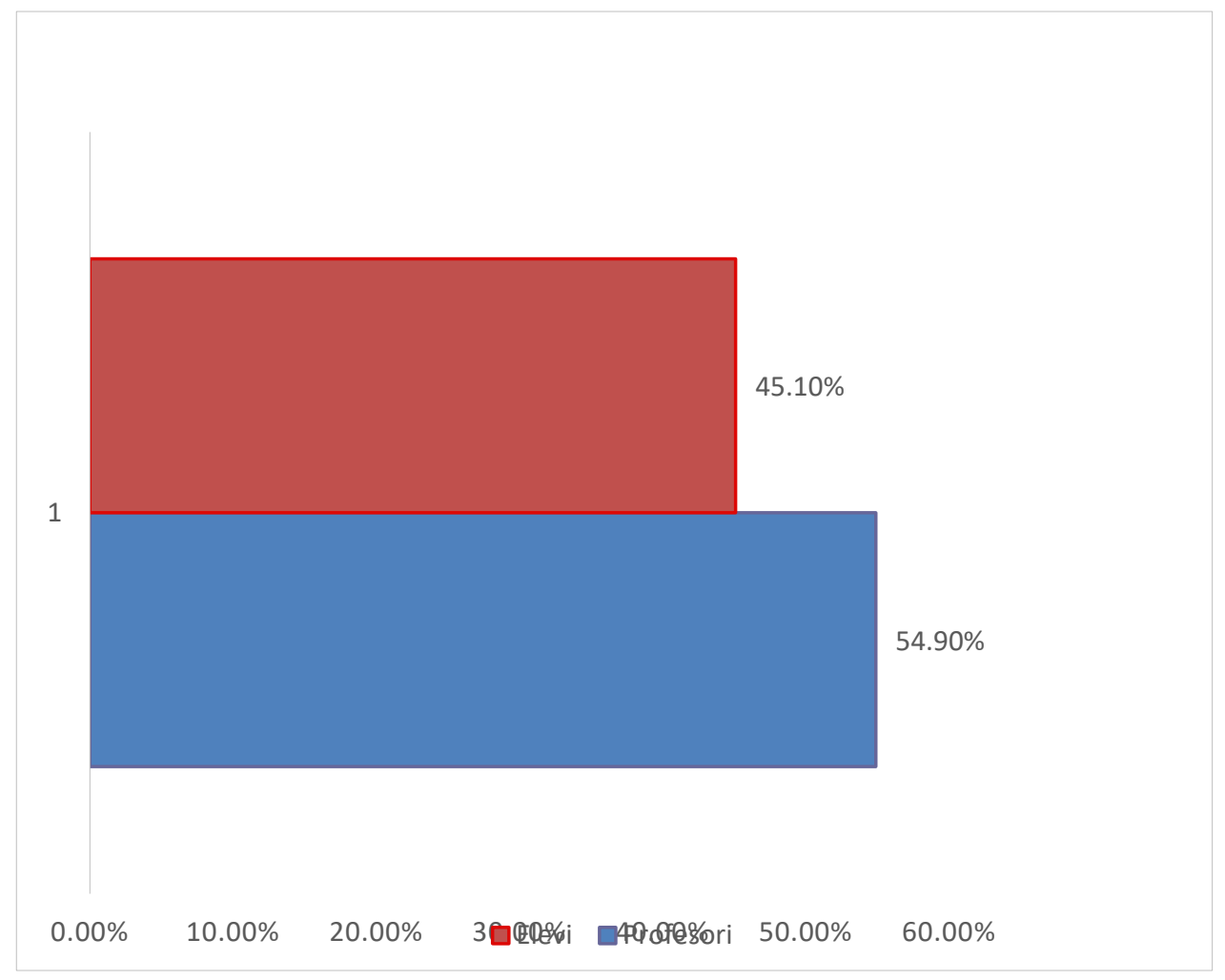

PICBE $\mid 1078$

Figure no.5 Student response regarding learning new debate structures or styles Source: Own elaboration based on the analysis in SPSS 22.

Another measurement concerned the skills of using the computer. Students were asked to self-report the extent to which they had the knowledge and skills of operating on the computer before and after participating in the project. The tool contained six items relating to personal purchases before and after the project, which related to the use of Office Word, Film editing, Power Point, Skype, Hangout, or Google Drive software. To perform the statistical analysis we used the $\mathrm{t}$ test for paired samples which is a significance test and which tests the differences between two environments. The results are presented in tables 5 and 6 . The arithmetic mean of the level of knowledge before participating in the European program is Mânainte $=21.45$ and the average after participation is Mdupă $=22.44$. From a media point of view, there is a difference, but we do not know if it is significant or not. For this we check the results of the $t$ test. The result indicates the existence of a strong correlation between the two variables: $r=$ .860 , and $\mathrm{p}=.000$.

Table no. Error! No text of specified style in document. The stages of creating the obtained samples

\begin{tabular}{|l|l|l|l|l|}
\hline \multicolumn{2}{|c|}{} & N & Correlation & Sig. \\
\hline Pair 1 & Before \& After & 70 & .860 & .000 \\
\hline
\end{tabular}

Source: Own elaboration based on the analysis in SPSS 22.

The statistical results in the SPSS indicate that there is a significant difference between the average of the knowledge of the use of the computerized means before participating in the project, compared with the moment of finalizing the participation in the same project: $t(69)=$ $-4.162, \operatorname{sig}=0.000$. 
Tabel no.1 The stages of correlating the tests regarding the knowledge of computer use, before and after participating in the project

\begin{tabular}{|c|c|c|c|c|c|c|c|c|c|}
\hline & & & $\mathrm{Pai}$ & d Differenc & & & & & \\
\hline & & Mean & $\begin{array}{c}\text { Std. } \\
\text { Deviation }\end{array}$ & $\begin{array}{l}\text { Std. Error } \\
\text { Mean }\end{array}$ & $\begin{array}{r}95 \% \mathrm{C} \\
\text { Interv } \\
\text { Diff }\end{array}$ & $\begin{array}{l}\text { idence } \\
\text { of the } \\
\text { nce }\end{array}$ & $\mathrm{t}$ & $\mathrm{df}$ & $\begin{array}{l}\text { Sig. (2- } \\
\text { tailed) }\end{array}$ \\
\hline & & & & & Lower & Upper & & & \\
\hline Pair 1 & $\begin{array}{c}\text { Before - } \\
\text { After }\end{array}$ & -1.37143 & 2.75666 & .32948 & -2.02873 & -.71413 & -4.162 & 69 & .000 \\
\hline
\end{tabular}

Source: Own elaboration based on the analysis in SPSS 22.

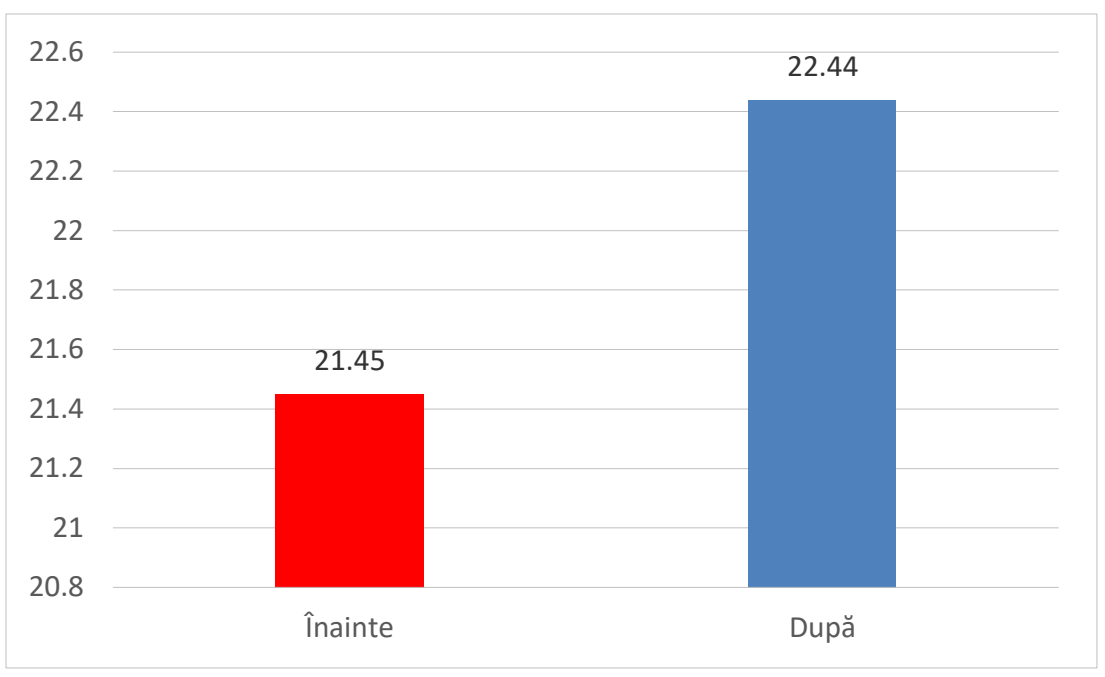

Figure no.6 The difference of environments regarding the knowledge of computer use before and after participating in the program, in the case of students

Source: Own elaboration based on the analysis in SPSS 22.

Respondents also provided answers to a question regarding the extent to which teacherstudent or student-student communication and cooperation improved as a result of participating in the project. The self-reported responses, according to the participants' perception, were positive, the arithmetic mean on a scale from 1 to 5 , where 1 means "not at all" and 5 "very much", was $3.6282(\mathrm{~N}=80)$. Turned into percentages, $72.56 \%$ of the students reported that the two, namely communication and cooperation between them and their teachers, or between them and their colleagues, improved, while $27.44 \%$ answered negative. 


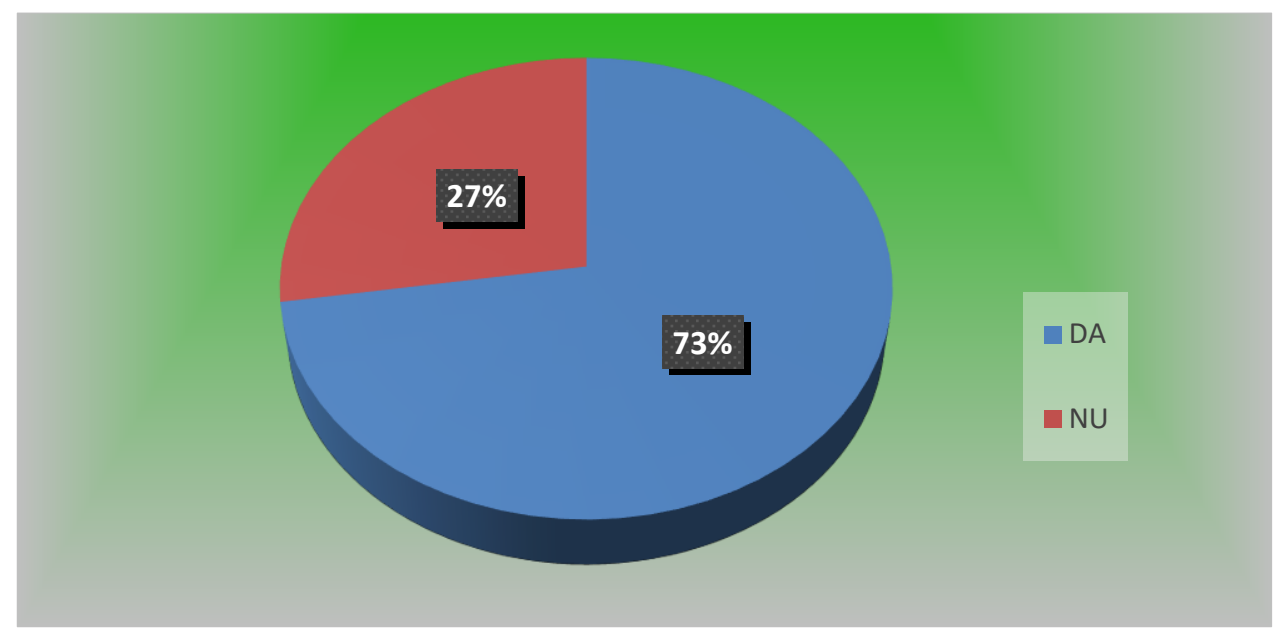

PICBE $\mid 1080$

Figure no.7 Frequency of participants' responses on improving communication and cooperation between educational agents (transformation into dichotomous response)

Source: Own elaboration based on the analysis in SPSS 22.

Also, to the question "Has your project determined you to become more inclined to practice teamwork in the future?", The students answered unanimously (100\%) yes:

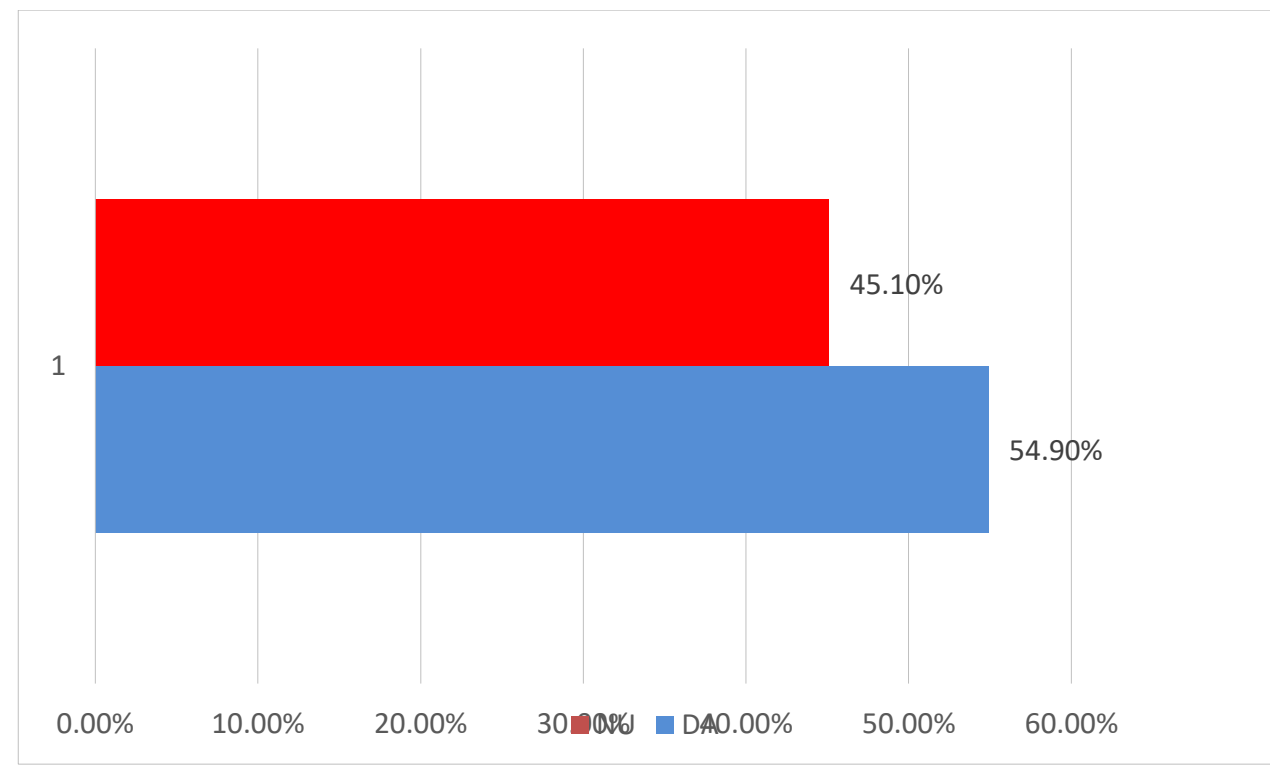

Figure no.8 Participants' answers regarding teamwork

Source: Own elaboration based on the analysis in SPSS 22.

A percentage of $54.9 \%$ of the students indicated that the project helped them to become more prone to teamwork in the student relationship, and $45.1 \%$ indicated that the project helped them to become more prone to teamwork in the relationship. between teachers and students.

\section{Conclusion}

Following the statistical analysis, the results indicated that overall the project had a positive effect on the human resource participating in the project.

- Regarding the learning of new debate structures or teaching-learning-evaluation styles, $73 \%(\mathrm{~N}=60)$ of the teachers responded positively, and $27 \%$ negative, unlike students who answered positively in a smaller percentage. (54.90\%), 45.10\% answering negative. - The t-test for paired samples indicated that both teachers and students made significant 
progress on computer use skills, but there are differences between them. Overall, students appear to have more computer use skills when they enter the program and, as a result, have reported a higher level of acquired competence. There are also numerical differences between student progress and teacher progress. The teachers made a progress of 2,548 times higher than the students. This is probably due to other variables that have not been measured. Teachers may have a greater ability or desire to acquire knowledge in this area compared to students.

PICBE | 1081

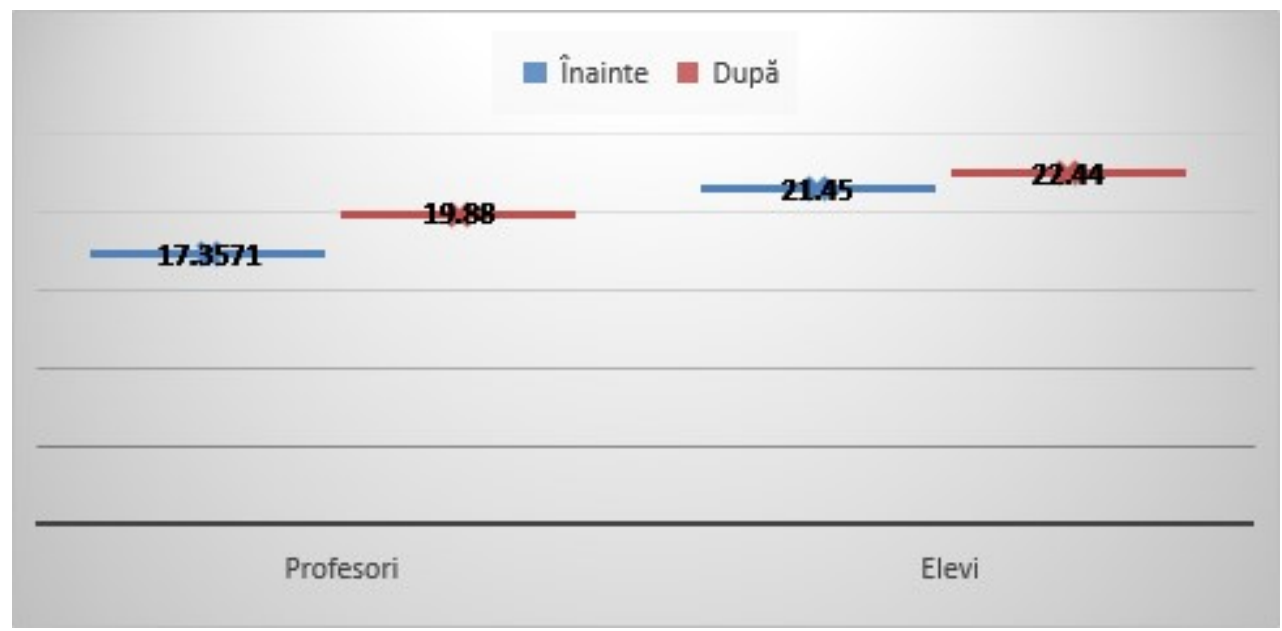

Figure no.9 Comparison of the performance values before and after the entry of teachers and students

Source: Own elaboration based on the analysis in SPSS 22.

- More teachers $(93.3 \%)$ reported that they improved communication and cooperation in their relationships with students than students $(72.56 \%)$, who reported better relationships with teachers (Figure 5-10). . Only 6.7\% of teachers did not report any improvement in relationships, and more than $27.44 \%$ did not report any improvement among students.

- Finally, the analyzes show that both teachers and students became more likely to practice teamwork in the future, due to participation in the project. The percentages were equal, and the answers were unanimous in both situations, both for teachers and students.

\section{Limits of research}

1. Because the data were self-reported, the predisposition of the pattern of responses was observed, which may occur under external evaluation conditions. 2. European projects do not always benefit from questionnaires or well-prepared databases to carry out a comprehensive and comprehensive assessment of the effects of the project.

3. The present research found conclusive evidence regarding the effect of the project intervention on the human resource, but the existence of richer data could have completed the picture of the relationship between the objectives achieved in the project and their effects on the beneficiaries.

4. From the analyzed data, we can observe the relationships that are established between teacher-teacher, teacher-student, student-student, lasting relationships, cooperation and collaboration.All these results lead us to assert that European programs help to improve cooperation and communication between different nations. 


\section{Acknowledgement}

This work is supported by Project POCU 125040, entitled- Development of the terțiar university educational to suport the economic growth-PROGRESSIO, co-financed by the European Social Fund unde Human Capital Operaţional Program 2014-2020.

\section{References}

Kirchsteiger, G., \& Sebald, A. (2010). Investments into education- Doing as a the parents did. European Review, , 54(4), 501-516. 2. Krueger, B., \& Lindahl M. (2001). Education for Growth: why and for Whom?. Journal for Economic Literature, 1130.

Long, M.C. (2010). Changes in the returns to education and college quality. Economics of Education Review, 29(3), 338-347.

Mâţă, L., \& Suciu, A. (2011). Curricular innovative model focused on developing pedagogical competences of teachers of Language and communication. Procedia Social and Behavioural Sciences, 12, 274-282.

Ministerul Educţiei şi Cercetării (1988). Perspectives et taches du developpement de l'education en Europe a l'aube d'un nouveau milenaire. Paris, UNESCO, 21-27 septembrie 1988, InEducaţie-învăţământ, Învăţământul în alte ţări, Oficiul de Informare Documentare pentru Învăţământ.

Pelinescu, E. (2015). Procedia Economics and Finance, 22, 184 - 190. 